\title{
Effectiveness of LMS Assisted by Schoology on Parabolic Motion on Learning Outcomes of Health Vocational Students
}

\author{
Dewi Oktaviyanti $^{1}{ }^{1}$, Sari Sri Sukmawati ${ }^{2)}$, Eni Setyawati ${ }^{3)}$, Diah Ratnasari ${ }^{4)}$, Suritno Fayanto ${ }^{5)}$ \\ 1)* Program Pascasarjana Pendidikan Fisika, Universitas Ahmad Dahlan \\ ${ }^{2,3,4,5)}$ Program Pascasarjana Pendidikan Fisika, Universitas Ahmad Dahlan \\ *Korespondensi Author Email: Dewi1707041010@webmail.uad.ac.id
}

\begin{abstract}
Abstrak: Penelitian ini bertujuan untuk mengetahui efektifitas Learning Management System (LMS) berbantuan Schoology pada materi parabola terhadap hasil belajar siswa di SMK Bhakti Indonesia Medika Pacitan. Jenis penelitian yang digunakan adalah pre-eksperimental design dengan one group pre-test post-test design. Sampel penelitian ini adalah siswa kelas X SMK Kesehatan Bhakti Indonesia Medika Pacitan. Analisis data dalam penelitian ini menggunakan One-Sample T-Test dengan SPSS 23. Berdasarkan hasil penelitian didapatkan rata-rata persentase peningkatan hasil belajar siswa yang menggunakan skoologi berbantuan LMS pada materi parabola adalah $25 \%$. Dengan menggunakan One Sample T-Test, sig. (2-tailed) Nilai 0,000<0,05, secara statistik ada perbedaan antara sebelum dan sesudah menggunakan Schoology berbantuan LMS. Hasil angket usability menunjukkan bahwa rata-rata untuk setiap aspek adalah 79\% (kemanfaatan), 67,2\% (kemudahan penggunaan), 67,50\% (kemudahan belajar), dan $64 \%$ siswa puas (kepuasan).
\end{abstract}

Kata kunci: Manajemen system pembelajaran, Schoology, Gerak parabolik, hasil belajar, blended learning, kognitif siswa

Abstract: This study proposed to determine the effectiveness of the Learning Management System (LMS) assisted Schoology on parabolic material in student learning outcomes at the SMK Bhakti Indonesia Medika Pacitan. The study was a pre-experimental design with one group pre-test post-test design. The sample of this research was students of X SMK Kesehatan Bhakti Indonesia Medika Pacitan. The data analysis in this study used the One-Sample T-Test with SPSS 23. Based on the result, the average percentage of increase in student learning outcomes using LMS assisted schoology on parabolic material was 25\%. By using the One Sample T-Test the sig. (2-tailed) Value of 0,000 $<0,05$, statistically, there was a difference between before and after using the LMS-assisted Schoology. The usability questionnaire showed that the average for each aspect is 79\% (usefulness), 67.2\% (ease of use), 67.50\% (ease of learning), and $64 \%$ of students are satisfied (satisfaction).

Keywords: $\quad$ Learning management system, Schoology, Learning aoutcomes, Blended learning, Cognitive student, Parabolic motion

\section{INTRODUCTION}

Education is a necessity for every human being in life and will continue to develop, along with the advancement of science and technology (Fayanto et al. 2019). Education is a conscious and planned effort to realize learning and learning processes so that active students develop the potential associated with improving religious, spiritual, self-control, motivation, noble character, and skills that needed society, nation and country. Learning is an activity that cannot do from human life; by learning, humans can develop the potential, they carry from birth. Learning are activities that take place from birth or last a lifetime.

The technologies are growing so fast. The development of information technology in the world of education is an important component to be developed in the learning process (Muler, 2014). The development of technology is an innovation that can offer effectiveness and creativity in teaching and learning (henriksen et al. 2016). However, the learning process in SMK Kesehatan Pacitan, teachers still use conventional models and have not maximized technology as a medium for delivering the material.

In the teaching and learning process, an evaluation material needed as a measure of the success of students in understanding the material delivered by the teacher. Evaluation materials can be written tests, oral tests, practices, and quizzes. Technology can be applied for teaching materials and evaluation materials in the learning process. 
One of the uses of online learning technology is the learning management system (Fathema et al. 2015). Through online learning technology teachers and students can interact without having to face to face at school, even with learning like this teachers and students do not need to worry about the limitations of space and time.

Learning management system is a prevalent learning management system, where the system can create a virtual learning environment between teachers and students. Virtual environment based learning can be used in an abstract or unrealistic learning model (Piccoli et al. 2001). A teacher can use virtual classes as a solution by utilizing the learning management system. In physics learning, there are still many students who do not fully understand the physics material; one of the causes of student learning interest is still declining (Argaw et al. 2016). One of the factors decreasing students interest in learning is because of the availability of media and teaching materials that are still less interesting in learning. So that there is no desire of students to learn and understand physics, one of them is the parabolic motion material. By using the learning management system in the form of Schoology with several features contained in it, students can explore more about the material to be learned and make learning more enjoyable. In addition, students can discuss and exchange opinions with other students.

The purpose of the implementation of the learning management system through schoology in SMK Kesehatan Pacitan is to support active and independent student learning as measured by student learning outcomes. In this learning, the teacher acts as a facilitator, and the teacher is not the only source of learning. Learners can interact and exchange information and look for references from other sources. Schoology serves as a media sharing, discussion, and learning together by utilizing the features and facilities that are in it (Kaufman \& Kumar, 2018). By applying this learning involves the activeness of the teacher and students, which are expected to increase student learning interest, which then has a positive effect on their learning outcomes.

\section{METHOD}

The technique used in this research was preexperimental design with group pre-test post-test design. This design can be represented as follows:

Table 1. Experiment Design

\begin{tabular}{lll}
\hline $\mathbf{O}_{1}$ & $\mathrm{X}$ & $\mathrm{O}_{2}$ \\
\hline
\end{tabular}

With $O_{1}$ is Pre-test, $\mathrm{O}_{2}$ is Post-test, and $\mathrm{X}$ is Treatment in the form of learning using LMS (Schoology). The population in this study were students of class $\mathrm{X}$ in SMK kesehatan pacitan with ten students. data collection technique used measurement techniques from pre-test and post-test. The test is a multiple choice test with three choices. The questions given were ten questions and adopted from the research (Wiranata,
2017). Each question in the pre-test and post-test represents the same concept

To measure the learning model carried out by utilizing information and communication technology can be well received by students and according to the expectations of learning, the usability questionnaire known as the USE questionnaire is used (Lund, 2001). The scale used is the Likert scale.

Table 2. Likert Scale

\begin{tabular}{lll}
\hline No & \multicolumn{1}{c}{ Statement } & Score \\
\hline 1 & Strongly Agree & 4 \\
\hline 2 & Agree & 3 \\
\hline 3 & Disagree & 2 \\
\hline 4 & Strongly Disagree & 1 \\
\hline
\end{tabular}

\section{RESULTS AND DISCUSSION}

\section{A. Enhancement Learning Outcomes}

To find out the percentage of improvement in student learning outcomes using a learning management system assisted by schoology on parabolic motion material, the pre-test and post-test data were analyzed first. The pre-test was carried out using a printout problem while the post-test was carried out using the Quiz feature found in schoology, as shown in Figure 1. 


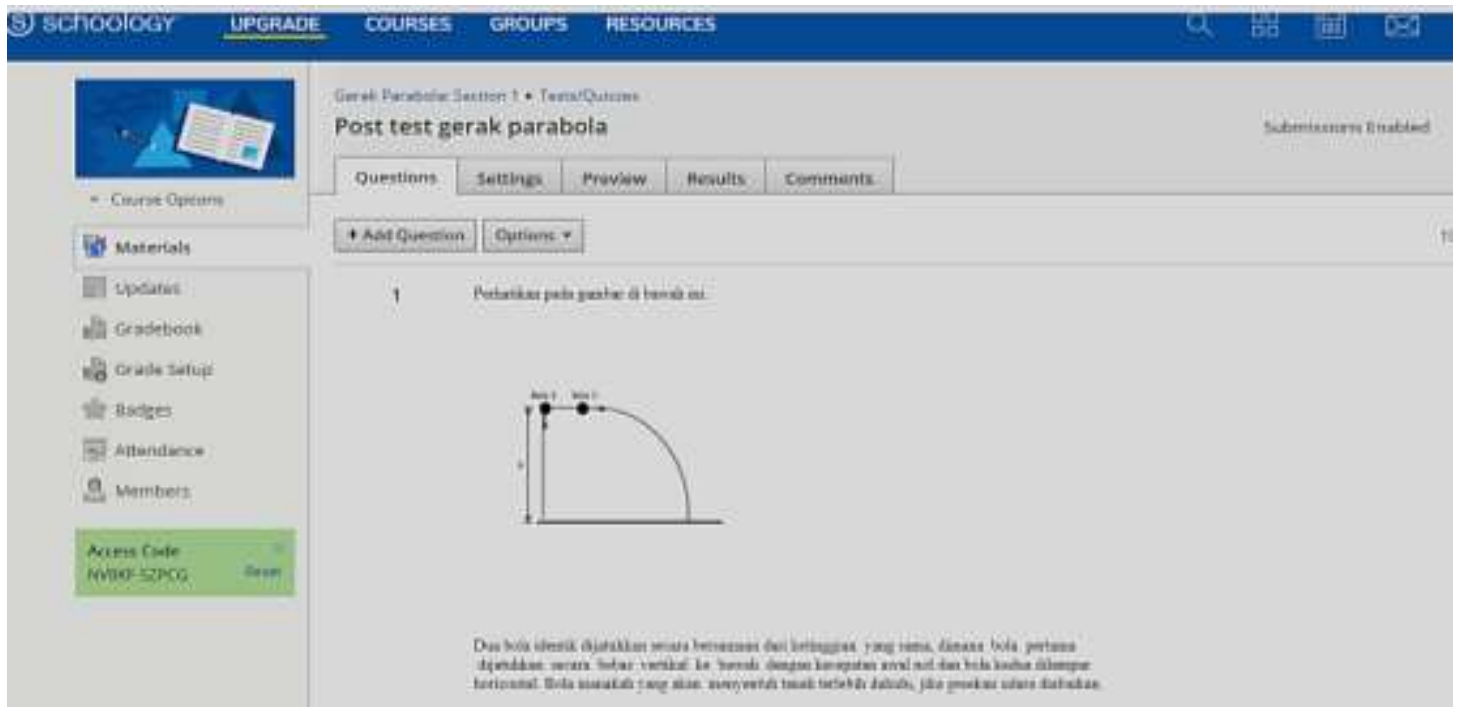

Figure 1. Post-test parabolic motion

Furthermore, the percentage of learning outcomes calculated as in Table 3.

Table 3. Result of Pre-test and Post-test

\begin{tabular}{cccccc}
\hline & \multicolumn{2}{c}{ pre-test } & \multicolumn{2}{c}{ post-test } & \multirow{2}{*}{$\mathbf{X}$} \\
Student Code & $\mathbf{X t}$ & $\mathbf{\%}$ & $\mathbf{X t}$ & $\mathbf{\%}$ & \\
\hline MRA & 4 & 40 & 7 & 70 & 30 \\
CN & 3 & 30 & 6 & 60 & 30 \\
RAR & 4 & 40 & 7 & 70 & 30 \\
SS & 1 & 10 & 3 & 30 & 20 \\
WRER & 3 & 30 & 5 & 50 & 20 \\
ABI & 3 & 30 & 4 & 40 & 10 \\
YL & 2 & 20 & 6 & 60 & 40 \\
LFS & 3 & 30 & 6 & 60 & 30 \\
IP & 2 & 20 & 4 & 40 & 20 \\
SR & 3 & 30 & 5 & 50 & 20 \\
\hline Avarage & \multicolumn{2}{c}{$28 \%$} & \multicolumn{5}{c}{$53 \%$} & $25 \%$ \\
\hline
\end{tabular}

Based on the data analysis above, the average increase in student learning outcomes is $25 \%$. When viewed from $\Delta \mathrm{X}$, each student experiences a change that is almost the same, which ranges between 20-30 percent. The smallest change occurs at $10 \%$ as much as one person, and the highest is $40 \%$ and as many as one people. This increase in learning outcomes can be caused by the ease of students in understanding the concept of parabolic motion by being given a video and practice assisted by youtube and PhET media, which linked through schoology. The use of schoology which is supported by various forms of media such as video, audio, and images that can attract students' interest, and interest is one indicator of learning motivation that can improve learning outcomes (Ulfa et al. 2017).

B. Effectiveness of LMS Learning is assisted by schoology on learning outcomes

To find out the Effectiveness of LMS Learning, which assisted by schoology, it is calculated using a test sample t-test, and the results obtained, as shown in Figure 2. 
One-Sample Test

\begin{tabular}{|c|c|c|c|c|c|c|}
\hline & \multicolumn{6}{|c|}{ Testivalug $=0$} \\
\hline & \multirow[b]{2}{*}{1} & \multirow[b]{2}{*}{ df } & \multirow[b]{2}{*}{ Sig. (2-tailed) } & \multirow{2}{*}{$\begin{array}{l}\text { Mean } \\
\text { Difference }\end{array}$} & \multicolumn{2}{|c|}{$\begin{array}{l}95 \% \text { Confidence Interval of the } \\
\text { Difference }\end{array}$} \\
\hline & & & & & Lower & Upper \\
\hline pretest & 9,635 & 9 & .000 & 2,80000 & 2,1426 & 3.4574 \\
\hline posttiest & 12,531 & 9 & ,000 & 5,30000 & 4,3432 & 6,2568 \\
\hline
\end{tabular}

Figure 2. Data analysis used the one sample t-test on SPSS

The significance level used in the one sample t-test analysis test is 0.05 . If the Sig value is $<0.05$, LMS learning assisted by schoology on parabolic motion material is effectively used to improve student learning outcomes, conversely if the Sig>0.05 then LMS learning assisted by schoology on parabolic motion material is not effectively used to improve student learning outcomes. From the results of the test data analysis of one sample ttest obtained a significance level of 0,000 which means that the value of sig $<0.05$, this indicates that learning
LMS assisted by schoology on parabolic motion material is effectively used to improve student learning outcomes

C. The usability of the LMS model assisted by schoology for learning

Aspects measured by questionnaires include usability (usefulness), ease of use (ease of use), ease of learning (ease of learning), and satisfaction (satisfaction). The results of the questionnaire can be seen in table 4 and figure 3 .

Table 4. The results of the use questionnaire by students

\begin{tabular}{cccccccc}
\hline \multicolumn{2}{c}{ Usefulness } & \multicolumn{2}{c}{ Easy to Use } & \multicolumn{2}{c}{ Easy to Learn } & \multicolumn{2}{c}{ Satisfaction } \\
\hline STS & $0 \%$ & STS & $0 \%$ & STS & $0 \%$ & STS & $0 \%$ \\
TS & $1 \%$ & TS & $16.36 \%$ & TS & $10 \%$ & TS & $3 \%$ \\
S & $79 \%$ & S & $67.27 \%$ & S & $67.50 \%$ & S & $64 \%$ \\
SS & $20 \%$ & SS & $16.36 \%$ & SS & $22.50 \%$ & SS & $33 \%$ \\
\hline
\end{tabular}

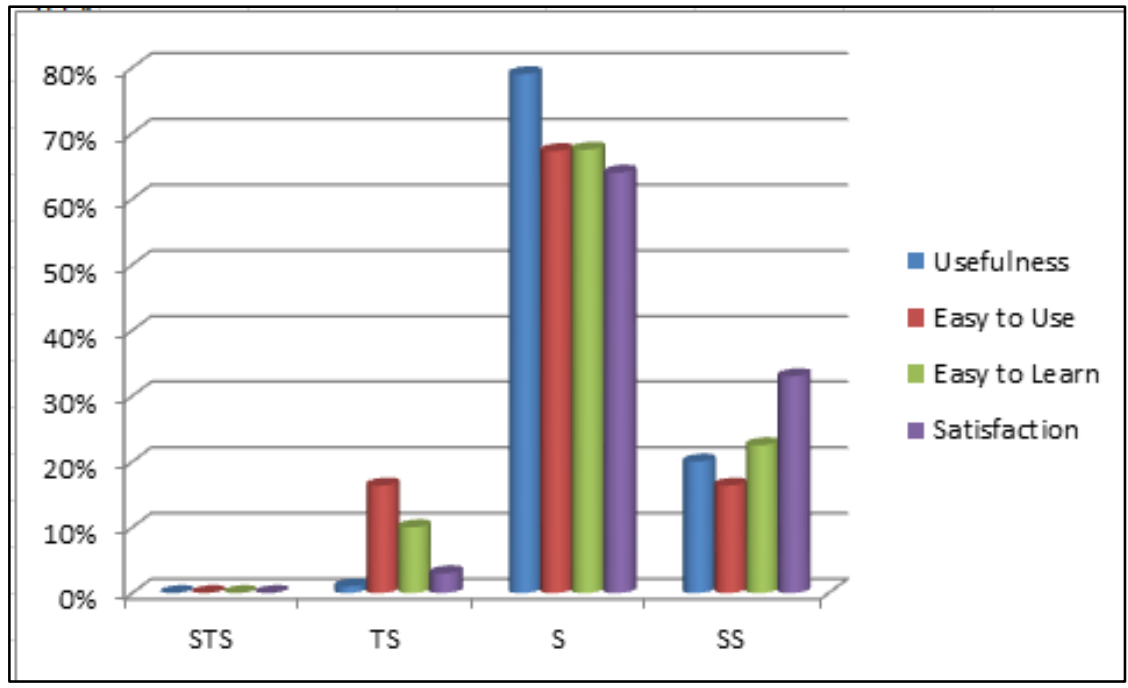

Figure 3. Graph of user response

It can be seen in the tables and graphs, that there are still students who consider the LMS learning Model to use schoology still high. However, the dominant student states that good and very good are relatively high for all aspects. From the calculations can be obtained, $79 \%$ of students agree that the LMS learning model is a useful 
schoology to help students in learning. Then $67.2 \%$ of students agreed that learning using the LMS model assisted schoology was easy to use (ease of use). Whereas, learning using LMS assisted by schoology is $67.50 \%$ of students agree with ease of learning in learning the material and use of the LMS itself, and $64 \%$ of students are satisfied in using the LMS learning model assisted by schoology to help them in the material circular motion. Based on the four aspects of assessment obtained, the level of student satisfaction gets the lowest score. In this because schoology cannot be used in all situations if there is no internet signal in a school or learning environment.

\section{CONCLUSION AND SUGGESTION}

The average percentage of increase in student learning outcomes using a learning management system (LMS) assisted by schoology on parabolic material was $25 \%$. LMS is learning with schology on parabolic motion material practical used to improve student learning outcomes. The usability questionnaire showed that the average for each aspect is $79 \%$ (usefulness), $67.2 \%$ (ease of use), $67.50 \%$ (ease of learning), and $64 \%$ of students are satisfied (satisfaction).

\section{REFERENCES}

Argaw, A. S., Haile, B. B., Ayalew, B. T., \& Kuma, S. G. (2016). The effect of problem based learning (PBL) instruction on students' motivation and problem solving skills of physics. Eurasia Journal of Mathematics, Science and Technology Education, 13(3), 857-871.

Fathema, N., Shannon, D., \& Ross, M. (2015). Expanding the Technology Acceptance Model (TAM) to examine faculty use of Learning Management Systems (LMSs) in higher education institutions. Journal of Online Learning \& Teaching, 11(2).

Fayanto, S., Kawuri, M. Y. R. T., Jufriansyah, A., Setiamukti, D. D., \& Sulisworo, D. (2019). Implementation ELearning based moodle on physics learning in senior high school. Indonesian Journal of Science and Education, 3(2), 93-102.

Henriksen, D., Mishra, P., \& Fisser, P. (2016). Infusing creativity and technology in 21 st century education: A systemic view for change. Educational Technology \& Society, 19(3), 27-37.

Kaufman, D., \& Kumar, S. (2018). Student Perceptions of a One-to-One iPad Program in an Urban High School. International Journal of Research in Education and Science, 4(2), 454-470.

Lund, A. M. (2001). Measuring usability with the use questionnaire12. Usability interface, 8(2), 3-6.

Muller, J. (2015). The future of knowledge and skills in science and technology higher education. Higher Education, 70(3), 409-416.
Piccoli, G., Ahmad, R., \& Ives, B. (2001). Web-based virtual learning environments: A research framework and a preliminary assessment of effectiveness in basic IT skills training. MIS quarterly, 401-426.

Sicat, A. S. (2015). Enhancing college students' proficiency in business writing via schoology. International Journal of Education and Research, 3(1), 159-178.

Ulva, N. L., Kantun, S., \& Widodo, J. (2018). Penerapan ELearning Dengan Media Schoology Untuk Meningkatkan Motivasi Dan Hasil Belajar Siswa Pada Kompetensi Dasar Mendeskripsikan Konsep Badan Usaha Dalam Perekonomian Indonesia. Jurnal Pendidikan Ekonomi: Jurnal Ilmiah Ilmu Pendidikan, Ilmu Ekonomi Dan Ilmu Sosial, 11(2), 96-102.

Wiranata, A. (2016). Pengaruh Strategi Pembelajaran Konflik Kognitif terhadap Peningkatan Pemahaman Konsep Siswa Pada Materi Gerak Parabola (Doctoral dissertation, Tanjungpura University). 